\title{
Football as Code: the social diffusion of 'soccer' in South Africa
}

\author{
Lloyd Hill ${ }^{*}$ \\ University of Johannesburg
}

\begin{abstract}
This article explores the processes associated with the emergence of rugby and soccer as distinct 'sporting codes' in South Africa. Beginning with an elaboration of the concept of 'sporting code', the author traces in broad brush the events that transformed the two English codes into new forms of cultural capital in transnational sporting fields. Set against this wider context, the focus then shifts to the 'social diffusion' of rugby and soccer in the territories that would subsequently constitute the South African state. It is argued that between 1859 and the discovery of gold in 1886 rugby and soccer emerged in two relatively distinct fields, centred on the British Cape and Natal colonies. The article then explores the stratification of these fields, following the establishment of the Union of South Africa in 1910. Particular attention is given to the relative status of rugby and soccer in the colonial education systems and in the post-1910 national education system.
\end{abstract}

\section{Introduction}

The sociology of sport is relatively underdeveloped in South Africa. ${ }^{1}$ A lot has been written on sport, but most publications have tended to be produced from the perspective of the 'sportsman' (mostly men) or from the perspective of 'the sporting code', which is to say focused on the internal development of a specific sport - the history of teams, fixtures, clubs, record tables and regional/national governing bodies. In South Africa these 'code chronicles' have more often that not tended to celebrate sporting achievements in the 'establishment sports' - notably cricket and rugby and to underplay the associated history of racial fragmentation and discrimination.

At issue for the sports sociologist is the need to move beyond sporting hagiography in general to explore the social significance of sport in South Africa. The problem with sporting hagiography is that it tends to overstate individual prowess and

\footnotetext{
*Email: lhill@uj.ac.za.
} 
to understate key social, economic and political factors that cannot be reduced to individual action. Sport may be studied 'for itself', or as an autonomous system of ideas and practices, but this comes at the cost of understanding underlying social processes. One of the objectives of this paper is therefore to show how sport has helped to 'codify' the relationship between key social categories, notably those of race $^{2}$, class and gender.

The tendency towards hagiography is not unique to South Africa. It can be categorized under a more general tendency to read history teleologically, which is to say the tendency to reconstruct history from the perspective of one's experience of the present. Avoiding this problem is no easy matter, even for the professional historian. Moreover, we live in an age in which the social significance of languages in the construction of texts - and markets for texts - has emerged as a key methodological issue in the social sciences. The objective should therefore be to recognise teleology as an inherent tendency in the writing (and publishing) process and to strive to limit it. The comparative method provides one means of doing this and in this article takes the form of a comparative exploration of the 'diffusion' of two football codes - 'rugby' and 'soccer' - in South Africa.

The article has three main objectives. Firstly, my analysis begins with the observation that the two codes in question have a history that predates the English terms that are now routinely used to distinguish them. I explore these terms, within the context of a broader discussion of the older concepts of 'football' and 'code.' Secondly, I elaborate a distinction between the diffusion of technical innovation and the 'accumulation' of a social or cultural code. Drawing on the work of Bourdieu, I argue that the spread of the major British sporting codes can be understood in terms of the establishment of transnational sporting fields, in which alternative codes are 
displaced and in which the major English codes function as new forms of cultural capital.

Finally, I provide a comparative analysis of the social diffusion of rugby and soccer in South Africa between 1859 and approximately 1930. My analysis of the spread of the codes examines the role played by different institutions, including schools, military units and the media. Particular attention is given to the emergence of a national education system - in the context of an Empire-wide field of English education - and the role that stratified education played in the attribution of social status to the two codes before and after the unification of the state in 1910 .

\section{'Football' as a sporting code}

In many parts of the world the English word 'football' is commonly used to refer to the world's largest 'sporting code' - association football or 'soccer'. This symbolic practice tends to obscure the fact that the term 'football' currently refers to a variety of sporting codes, including rugby football (Rugby Union and Rugby League), Gaelic football, American football, Canadian football and Australian rules football. The close historical association between the main alternative codes and the Anglophone nations is evident in this list. The historical significance of the English language is also evident in the manner in which the word 'football' - designating the association game - has been translated into numerous other languages. Thus, whereas the French football is clearly a borrowed word-as in the Fédération Internationale de Football Association (FIFA) - the more widespread tendency has been to calque the word into the native language. ${ }^{3}$ One notable exception is the Italian 'calcio', which simply means 'kick', but which also evokes the memory of football traditions dating back to the Roman Empire. ${ }^{4}$ 
The etymology of the word 'football' is thus a useful point of departure for an article on the origins of association football. The English word 'Football' has Germanic origins, deriving from the combination of the Old English word ' $\mathrm{fō} t$ ' and the Old Norse 'böllr.' Written references to 'football' date back to the fourteenth century $^{5}$ - the period in which Middle English began to replace French as the language of record in England. ${ }^{6}$ There are however, earlier documented references to a football-like game called 'soule' (in French) or 'choule' (in Norman French) dating back to twelfth century France and England. ${ }^{7}$ Anglophone historians have adopted the term 'folk football' to distinguish earlier forms of football in Europe from the modern 'codes' that arose in England during the nineteenth century.

One way to think about the relationship between 'folk football' and modern forms of the game is to consider the manner in which we use the term 'code' to refer to 'a type of sport.' The word 'code' derives from the Latin term 'codex', whose literal sense was "a block of wood that could be split into 'leaves' or 'tablets",. 'Code' derives from 'codex' and enters English via French - the earliest English record dates to $1303 .{ }^{9}$ The sense of 'code' as a "systemic collection of laws and statutes" is established in English during the fourteenth century. The association with a system of military and telegraphic signals dates from the nineteenth century. ${ }^{10}$

Bourdieu $^{11}$ notes the historical shift in the use of the word 'code' from law to linguistics, and it is this shift that is particularly relevant to the study of sport (and other cultural domains). At issue is the use of language in the process of 'systematizing' a field of human endeavour.

What then is the change in the processes of systematization associated with the shift from folk football to the modern codes? It is not simply the existence of written codes that makes the difference, but rather their institutionalization in new and highly 
stratified forms of social structure - notably 'the market' and the 'nation state.' To understand the relationship between sport and power it is necessary to explore the process whereby a code or symbolic system develops, over time, to be manifested as a form of cultural capital.

\section{Codes, Imperial 'Diffusion' and Cultural Capital}

The problem with the use of the term 'diffusion' to describe the spread of a sporting code such as soccer is that it invokes 'a hydraulic imagery' ${ }^{12}$ in a manner that suggests widespread consensus on the value of the new code. Like ink diffusing through water or a sheet of blotting paper, new cultural practices are assumed to have spread 'naturally' from one community to another.

'Soccer' and 'rugby' are not simple 'good ideas' with associated techniques or 'skills'. They are instead complex systems of ideas and practices, which carried in their transportation much of the cultural baggage associated with their context of origin. And if the modern codes have a distinct point of origin (England), they also have a wider stratified context of original 'diffusion' - Empire.

Given this context, one means of exploring the rise of soccer is to trace its development, not simply as a codified and organized sport, but also as a form of cultural capital. This requires an attempt to explain the spread of a cultural code, not so much in terms of 'diffusion', but rather in terms of 'accumulation' at different points and at different levels within the stratified social space that constituted the British Empire. To this end, Bourdieu's elaboration of cultural capital in terms of three manifestations or states of cultural capital is useful. ${ }^{13}$

Firstly, cultural capital exists in the embodied form of cultivated dispositions, which are acquired through socialization. Socialization is the process of developing an 
appreciation of cultural goods, which can only be "consumed" by apprehending their meaning. This form of cultural capital exists in an embodied state- the mental and physical dispositions that constitute the 'habitus.' 14

Secondly, cultural capital takes an objectified form, such as books, instruments, works of art and sporting paraphernalia such as footballs. Objectified cultural capital is transmissible in material form, but its appreciation or 'consumption' requires specialized cultural abilities or embodied capital. Objectified goods are therefore appropriated both materially and symbolically.

The accumulation of objectified forms or artefacts is patterned, and powerful forms of organisation constitute a third category, or institutionalized form of cultural capital. 'Field' is the key spatial metaphor in Bourdieu's work. Cultural fields are structured spaces organised around specific combinations of capital. 'Field' functions as a more inclusive concept than 'market' to the extent that it suggests rank and hierarchy as well as exchange relations between producers and consumers. Bourdieu uses the term "doxa" to describe the fundamental commitment to the stakes of the field among both advocates of orthodoxy and heterodoxy alike. ${ }^{15}$ 'Field' is a useful and metaphorically appropriate ${ }^{16}$ concept in the study of sport. It is also useful in an exploration of the origins of 'association football' as a heterodox colonial code.

\section{'Soccer' as an Ascendant Form of Cultural Capital}

The use of term 'social diffusion' is intended to convey both the ideological dimension of 'accumulation' and the material conditions that underpin ideological conflict. In early nineteenth century England the key material conditions were those associated with the onset of industrialization. The particular ideological conditions that concern us here were the symbolic processes associated with the industrialization 
of leisure, in what came to be known as the 'rational recreation movement. ${ }^{17}$ One component of this movement involved an attempt to distil a subset of physical activities or 'sports', of which football was considered especially conducive to training young men and to defending the Empire. ${ }^{18}$

'Athleticism' therefore emerged as a key component of the colonial 'doxa' that underpinned the development of formal school sport in early nineteenth century England. Athleticism, it has been argued, is an educational ideology that emerged in the mid-Victorian public school system, but which subsequently "proved to be the nodal point for an ever-expanding imperial pedagogical web". ${ }^{19}$ Religious institutions and (initially Anglican) teacher training colleges also played a particularly significant role in transmitting athleticism to the English working classes, notably from 1888, when the vehicle of choice was association football. ${ }^{20}$

Athleticism was manifested in specific 'codes', which were 'played out' on an Empire-wide field. The irony is that, of the football codes, it is soccer - the sport least favoured by the colonial elites ${ }^{21}$ - that has transcended the boundaries of the Empire to become 'the global game.' In this section I focus specifically on key factors accounting for the rise of soccer as the dominant football capital in the United Kingdom, as a prelude to a discussion of similar factors in South Africa. My analysis of the process is built on a distinction between three early 'fields' or contexts of diffusion in England: the public school field; the wider education system (including Universities and teacher training colleges); and amateur and professional adult clubs.

Goldblatt identifies four initial conditions, associated with late-nineteenth century industrialization, which played a particularly significant role in the social diffusion of football in the United Kingdom: the rise of real wages among the urban working class; the increase in leisure time associated with the introduction of a 5.5 
day working week; new developments in transport technology; and growing literacy, associated with the introduction of compulsory junior schooling. ${ }^{22}$

While these general conditions facilitated the emergence of 'football' as the favoured pastime among the English working class, education and literacy played a particularly significant role in the selection and transformation of specific football codes into new forms of cultural capital. The particular role of the Victorian public school in this process has been a matter of considerable debate among British football historians. There is little doubt that they played a significant role in codifying the dominant sports, but there is less consensus on how successful they were in transmitting these codes beyond the elite realm of the public school system. ${ }^{23}$

The oldest codified form of football is the Eton 'field game', which was first set down in writing in $1815 .{ }^{24}$ While this game is still played, it is only played at Eton and has therefore never formed the basis of a wider field. The public school in Rugby produced the first socially significant set of football rules in 1845 or 1846 . The publication of a soccer-like code followed at Eton in $1847 .{ }^{25}$ The rugby code owes its early distinction not to William Webb Ellis, ${ }^{26}$ but to the well-known headmaster of the school, Thomas Arnold. Arnold was not a sports enthusiast, but his educational reforms established Rugby as one of the leading public schools in the first half of the nineteenth century.

Standardization by means of written rules was a necessary, but insufficient condition for the establishment of large football playing and spectating publics. Whereas Rugby and other public schools gave an early advantage to the rugby code, at university level and adult club level this momentum was checked by the influential role played by southern schoolboys in the formulation of an inter-school and interclub standard. At Oxford and Cambridge the widespread recognition of a proto-FA 
code had its origin in new markets for two forms of objectified cultural capital: the rulebook and subsequent written commentary on 'the code'; and various forms of standardised football artefacts that followed the industrial production of the round ball.

The 'Cambridge Rules', first published in $1848^{27}$, forbade running with the ball and in so-doing established a soccer-like code as the first inter-public school standard for former public schoolboys entering the university. ${ }^{28}$ Cambridge therefore provided the first large-scale field for the production and consumption of a standardized football code. When, in October 1863, university alumni and local club representatives met at the Freemason's Tavern in London to form the Football Association, it was the subsequent discussion of the Cambridge Rules that created the first significant schism between those for and against running with the ball. ${ }^{29}$ 'The Football Association Laws' were firstly published in the press on 5 December 1863. These laws were subsequently published as a short book, whose widespread publication established the authority of the FA beyond the initial confines of London. ${ }^{30}$ Dissatisfaction with the new rules led directly to the formation of the Rugby Football Union in 1871. It is only after this date that a socially significant distinction between standardized 'handling' and 'dribbling' codes emerged. This social distinction is then marked most conspicuously by the derivation of the words 'rugger' and 'soccer' - university slang equivalents for 'rugby' and 'association' respectively - to refer to both the codes and the players identifying with them. ${ }^{31}$

Changes in the shape of the ball constituted a significant technical development influencing the 'diffusion' of the codes; one which sharpened the distinction between the codes and shifted the advantage - in terms of popular recognition - decisively in favour of association football. "The ball is round" 32 - but it 
was not always so. The original 'folk' football - a pig's bladder encased in leather was neither round nor pronouncedly oval in shape. The pig did not provide a very good template for ball standardization and early balls therefore varied considerably in terms of size, weight and shape. This changed with the industrial production of rubber. In 1854 the American inventor, Charles Goodyear, won a gold medal at the international exhibition in Paris for his vulcanized rubber football. Round rubbercored balls would subsequently "change the shape of Golf, Tennis and Football more than any other single factor". ${ }^{33}$ In the United Kingdom, Richard Lindon established the first soccer 'printing press' in the town of Rugby, where he was also commissioned to design the first rugby ball. The Rugby School sought to distinguish their ball from other schools and this was achieved by changing the shape from "pig's bladder plum to an exaggerated egg". ${ }^{34}$ This 'distinction' was however not immediately rendered as a standard. The round ball was codified by the FA in 1872 , when a law specifying the circumference of the ball was adopted. ${ }^{35}$ By contrast, the Rugby Football Union only endorsed 'ovalness' in 1892, when it adopted the Rugby School's 'Lindon Big-Side Match Ball' as the compulsory shape. ${ }^{36}$

The qualities associated with the round rubber ball, once transposed to the bodily experience of kicking a 'soccer ball', formed the basis of a new form of expertise or embodied capital. It remains an open question to what extent these qualities - and the 'internal' qualities more generally derived from the laws governing play, the field size and equipment - can be invoked to explain the success of soccer. Explanatory priority must however be given to the historical conditions that turned 'soccer' into an industrial phenomenon on a global scale. In addition to footballs, by the turn of the century factories were producing jerseys, boots, socks, caps, 
commemorative badges, plates, mugs, biscuit tins, statuettes and a wide range of mimetic football games. ${ }^{37}$

In summary then, while the role of elite public schools and universities in the selection of specific football codes is the subject of debate, the significance of the education system as a whole in the establishment of soccer as the dominant English football code seems difficult to dispute. By the end of the nineteenth century both rugby and soccer were being played in transnational 'fields' in which they functioned as distinct forms of cultural capital. Undivided, association football emerged as the dominant field, in which a professional code was played and appreciated across the class barrier. In contrast, through its resolute commitment to amateurism - following the split with the Northern Union in 1895 - Rugby Union emerged as a greatly reduced field, but one in which the amateur code served as a powerful means of elite closure. This is particularly evident from a comparative analysis of the manner in which the two football codes entered South Africa.

In the period before the establishment of a unified state in 1910, the pattern of early diffusion corresponded with two subfields that were initially centred on the two British colonies. Rugby emerged first within the expanding footprint of the Cape Colony and was bolstered by the nineteenth century Cape education system, which formed the basis of the national education system after 1910. Outside of the schools, the shift from ad hoc 'football' games to institutionally significant urban codes took place after 1880, the period in which association football became the dominant code in the 'home country'. Soccer established its first significant foothold in the Natal Colony, where schools, mission stations and colonial soldiers popularized the game. A soccer subfield developed along the Durban-Johannesburg axis after the discovery 
of gold in 1886. With the establishment of the Union of South Africa in 1910, both codes were firmly established in all the major urban areas.

\section{The Roots of Rugby Domination (1859-1886)}

English influence in South Africa was entrenched in 1806, when Britain replaced the Batavian Republic as the colonial power in the Cape Colony. The first English medium school was the South African College (SACS), a Calvinist (Scottish and Dutch) institution established in 1829. Not insignificantly, the first local variant of football emerged at the rival Anglican institution, the Diocesan Collegiate School (now commonly known as Bishops), which was founded in Cape Town in 1849.

In 1859 Canon George Ogilvie became headmaster of the Diocesan College, where he subsequently introduced a variant of football that he learnt during his studies, first at Winchester and then at St Andrew's College, Bradfield. This variant came to be known as Gog's football ${ }^{38}$ and has been cited as the earliest example of both rugby ${ }^{39}$ and soccer ${ }^{40}$ in South Africa. There is some merit to both of these claims, as the style has been described as a 'polygenetic game' - a combination of the games played during the 1840s at Winchester, Eton and Harrow, but filtered through St Andrew's College, were handling was probably permitted. ${ }^{41}$ This game formed the basis of an early inter-school rivalry between Bishops and Sacs.

The first recorded football match in Cape Town took place on Saturday 23 August 1862. The two sides consisted of "fifteen officers of the army and a like number of gentlemen in the civil service". ${ }^{42}$ This social division is very relevant as it is also evident at the other major port-based regions of South Africa. The oldest documented football match in South Africa was played in Port Elizabeth three months before the Cape Town game. This game was played on 'the Hill' in front of the Grey 
Institute and involved a 'home-born' and a 'colonial-born' team. ${ }^{43}$ Four years later, the earliest recorded game in the Natal Colony was played in Pietermaritzburg. The game was played on the market square between the City and the Garrison on 26 September 1866. A spectator commented that "the rules were systematically disregarded by both sides through the whole game." ${ }^{44}$

These early games provide insight into the role that football played in forging an early division between home or UK-born and South African-born white settlers in the two British colonies. In the Cape Colony the establishment of the University of the Cape of Good Hope in 1873 drew Dutch-speakers into the sporting milieu. Early higher education at the Cape took the form of specialist higher education divisions in elite high schools, which were subsequently referred to as colleges. In 1874 an "Arts Department" was established at the Undenominational Public School in Stellenbosch, providing English medium higher education in a predominantly Cape Dutch-speaking town. This established Stellenbosch as the third major educational institution in the Western half of the Cape colony. Babrow and Stent note the 'colonial-born versus mother country' competitive ethos in Cape football, which preceded the introduction of football to Stellenbosch. ${ }^{45}$

Cape Town also provides the earliest evidence of the role that sport played in the racial division of South African society. Gog's football spread to the adult community and the first adult club, the Hamilton Football Club, was established in 1875. A second club, Villagers, was established a year later. In 1878, following the arrival at the Cape of William Milton - an ex-England rugby player - Hamiltons switched to Rugby Union. A year later, following a feud between supporters of the two codes, the Villagers Club also switched to rugby. At a meeting held at the Hamilton club on 30 May 1883 the rugby laws became the basis of the first regional 
football association - the Western Province Rugby Football Union. ${ }^{46}$ In the same year the two Cape colleges adopted the rugby rules and joined the regional body.

During the early 1880 s the rugby game also spread to Cape communities and clubs that were not represented by the new Union. Nineteenth-century Cape Town had a very complex and unequal social structure. Abolition came in $1833 / 4$, but the social and geographical legacy of slavery persisted long after this date, forming an early template for the institutional racism of the twentieth century. A football club called 'Roslyns' was established in 1881 or $1882^{47}$, in a region that had previously been established by freed slaves and which, from 1867, became known as the Sixth District of Cape Town or 'District Six.' Subsequently, two more clubs - Arabian College and Good hopes - were established in the Malay Quarter (now known as Bokaap), which is situated on the slopes of the mountain in the old city. In 1885 these clubs established their own regional organization, the Western Province Coloured Rugby Union. ${ }^{48}$

Beyond Cape Town, the first significant institution associated with the spread of football was the colonial military. Early games of cricket and football frequently pitted civilian or 'colonial-born' sides against local regiments. In the years before 1886 however, the role of the military in propagating specific football codes is very unclear. As already noted, the earliest documented games were probably hybrid varieties and the Cape variety - Gog's football - clearly evolved into rugby. Not enough is known to state with any certainty what patterns of continuity existed between the early games and the new sporting institutions that began to emerge during the 1880 s. It is, however, very likely that the early impetus was for rugby in the Cape Colony and, after 1880 , for soccer in the Natal Colony. 
Difford argues that British regiments introduced the rugby game to King William's Town in 1878, which at this time was situated on the Cape colonial frontier. The game then spread south to East London, Grahamstown and Port Elizabeth. The Stellenbosch College was established in 1881 and this was followed, two years later, by the establishment of the Stellenbosch Rugby Club. By the early 1880s, Cape Dutch/Afrikaans facilitated the spread of rugby in the Cape beyond English-speaking communities. Difford argues that by 1883 rugby football was "well established in all the coastal belt of the old Cape Colony", from where it then spread inland to Kimberley, following the new railroad to the diamond mines. ${ }^{49}$

\section{The Arrival of Soccer $(1870$ - 1910)}

If the Cape Colony provided the incubator for rugby, the Natal Colony played a similar role with respect to association football. Pietermaritzburg was the capital of the Boer republic Natalia, before British colonization in the years after 1843 . With the rapid growth of the sugar industry in the 1860s, Durban was established as a significant site of English and indentured Indian settlement. As in the Cape, Natal football traces its roots to the English schools that were established during the second half of the century. School football is mentioned in the Natal Witness newspaper in 1870, but this was a rugby-like game or variant of Gog's football. ${ }^{50}$ An early 'carrying' tradition was established in Pietermaritzburg, and in neighbouring Hilton. Resistance to soccer came most notably from Hilton College after the arrival of the second headmaster, who was an ex-pupil of Rugby School. ${ }^{51}$

In contrast with the Cape Colony, soccer was established in the Natal school system at a relatively early stage. Sometime after 1870 both codes were being played in Natal schools. At this time Pietermaritzburg was the more established educational 
centre and an early stimulus for soccer came in the form of the Association Cup. Cup tie matches between three local schools "almost meant the snuffing out of rugby for some time". 52

Parker $^{53}$ points out that between 1870 and 1880 several clubs were playing 'socker' in Natal, making this region 'the home of the game in South Africa.' In 1880 a railway line began operating between Durban and Pietermaritzburg, and rapid transport facilitated the growth of both codes at school and club level. Inter-town rivalry fostered the growth of soccer during the 1880s. The first adult clubs to be established were the Pietermaritzburg County Football Club and the Natal Wasps Football Club. ${ }^{54}$ Although 'football' at this time still referred to both codes, the growing dominance of association football in the United Kingdom raised the status of this code in southern Africa. One important difference between the colonies was the absence of a relatively autonomous system of higher education in Natal. Close ties with Britain therefore shielded Natal from the influence of the Cape university. ${ }^{55}$ Another difference was the role played by the colonial military. The Anglo-Zulu War (1879) and the first Anglo-Boer War (1880-1881) brought large numbers of working class British soldiers to Natal and these soldiers tended to popularize soccer. ${ }^{56}$ The first regional soccer association, the Natal Football Association, was established in 1882. The combined effect of educational status, improved transport, new immigration and inter-club / inter-town rivalry fuelled the rapid growth of the association game as a form of cultural capital in Natal. It is, however, noteworthy that during the early 1880 s most of the Natal clubs continued to play both codes. ${ }^{57}$

The major stimulus for the widespread diffusion of the association code was the discovery of gold on the Witwatersrand in 1886. Gold mining stimulated the rapid development of Johannesburg as South Africa's major industrial hub. A corollary of 
this process was Durban's replacement of Cape Town as South Africa's premier port. With the opening of an inland railway in 1895, the Durban-Johannesburg nexus became the primary axis of industrialization and, as a consequence, also the main axis for the diffusion of soccer. ${ }^{58}$ Johannesburg soccer in 1886 and 1887 was described as "only of the rough and tumble order". ${ }^{59}$ In 1888 immigrants from Natal established the 'Alpha Club', which would later give rise to two more stable clubs, the Wanderers and the Wasps. Parker notes that soccer flourished with the influx of 'Outlanders.' 60 During this period an equivalent Dutch/Afrikaans term 'uitlander' was commonly used to refer to both English and Dutch immigrants settling on the Witwatersrand. ${ }^{61}$

The reference to 'outlanders' suggests the manner in which the two football codes were instrumental in shaping an early white South African identity - notably through 'white' sporting interaction between Johannesburg and Pretoria. In 1889-the same year in which the South African Rugby Football Board was formed-the Transvaal Football Association was established. In 1891 the first English rugby team to tour South Africa effectively demonstrated the superiority of the 'home country' by winning every match. ${ }^{62}$ In the same year the Western Province Football Association was established. Cape military units figured prominently in this formation. A year later English speaking civilians and military officers formed the South African Football Association (SAFA) ${ }^{63}$ By the mid-1890s numerous other sporting codes had been established by the 'home-born' and 'colonial-born' inhabitants of the region. An early survey of South African sport shows the significant role that sport and two languages played in forging a national white identity.

Climatically the country is well adapted for every branch of sport, and Afrikanders (colonial-born) owe their fine physique to the open-air life which they lead in their youth."64 
Here 'Afrikander' ${ }^{65}$ is racially exclusive, but linguistically inclusive, which is to say used to refer to both English and Dutch/Afrikaans colonial born 'whites'. Towards the end of the century growing tensions between 'Boer' and 'Brit' therefore belied a deeper 'doxic' convergence on a shared racial identity.

In 1897 a visit by the leading British amateur soccer team, the Corinthians, provided a major stimulus to the growth of soccer in South Africa ${ }^{66}$ While the second Anglo-Boer War (1899-1902) ${ }^{67}$ brought about the suspension of most sporting fixtures, the aftermath of the war saw a 'boom' in sports "due in great measure to the officers and men of the garrison towns and the fact that many well-known British sportsmen, who had served in the war, settled in the Transvaal". ${ }^{68}$ Alegi notes that soccer's popularity in the colonial army was unsurpassed and, therefore, the influx of nearly a half a million British soldiers "accelerated the spread of soccer in a dramatic fashion". ${ }^{69}$ According to Alegi, "African, Coloured and Indian men watched, and most likely played the game with British soldiers in besieged towns such as Kimberley, Ladysmith, and Mafeking". 70

By 1902 Britain had established economic and cultural dominance over the territories that would subsequently merge to form a new state. English was the dominant language of the new urban areas and colonial pastimes provided a means of both integrating and stratifying immigrant communities. While there is evidence that soccer was played in black communities before 1900, the rapid diffusion of the code beyond the ranks of the mission-educated African population dates from the beginning of the twentieth century. In 1899 a black team travelling under the auspices of the Orange Free State Football Association became the first South African side to tour the United Kingdom. While treated as a spectacle and humiliated on the field, 
this team nevertheless demonstrated a growing interest in the association code among players excluded from the recently established 'white' national structures.

Education also played a major role in the popularization of both football codes in African communities. As was the case in many regions of the Empire, a nascent English education system fostered a general commitment to the 'doxic' ideals of masculine athleticism, which was then manifested in the promotion of specific English codes and the displacement of traditional sporting activities. ${ }^{71}$ In African communities both football codes developed in the wake of cricket, which was the first English sport to be introduced by the various mission schools established during the nineteenth century. Cobley notes that:

The importance of sport as part of a "civilizing mission" was not lost on the missionaries, who introduced cricket, soccer, and other games to the christianized African elite being produced in their native institutions. Schools such as Zonnenbloem, Lovedale, Healdtown, and St Matthews were the seedbed for sport among the African petty bourgeoisie which began to emerge in the new industrial mining towns of Kimberley and Johannesburg at the end of the nineteenth and the early twentieth century. ${ }^{72}$

With this deep legacy established, the football codes 'diffused' initially within the urban populations of the Cape and Natal. Rugby predominated in the Cape Colony, where in 1896 the Western Province Coloured Rugby Union ${ }^{73}$ was established in Kimberley. Booley notes that at the first tournament held in 1898 "half the Eastern Province Team were Africans". ${ }^{74}$ These men would have been isiXhosa speakers from the eastern region of the Cape Colony, where rugby had established a strong presence in the mission schools. ${ }^{75}$

African soccer traces its roots to the Ifafa mission station near Durban. ${ }^{76}$ It was here that American missionaries first used the association game to propagate the ideals of athleticism. In 1902, at this mission station, the Rev. Onslow Carleton established the Bush Bucks Football Club. Alegi ${ }^{77}$ provides a detailed account of the 
rapid spread of soccer among the Kholwa (Christian Africans) in Natal. The Kholwa emerged as a significant subaltern class in Durban and Johannesburg. Literate in English and isiZulu, they played a significant role in the 'vernacularization of British football', ${ }^{78}$ which included the creation of indigenous spoken and written discourses on football and the development of new playing styles, or 'embodied' forms of the code. $^{79}$

Particularly influential among the Kholwa was John Langalibalele Dube (1871-1946), a minister and schoolmaster who went on to become the first president of the South African Native National Congress (later the African National Congress) in 1912. In 1903 Dube launched the Ilanga Lase Natal newspaper. ${ }^{80}$ Later shortened to 'Ilanga', this newspaper became the most influential African language newspaper in South Africa and is the only African language daily in the country at present.

In 1916 the first Natal African soccer organization, the Durban and District Native Football Association, was founded. Members of the Kholwa community that had settled on the Witwatersrand were also instrumental in popularizing and institutionalizing the game in Johannesburg. The first African clubs where formed on the mines, and mine clubs in turn established the first African regional organization in Johannesburg - the Witwatersrand and District Native Football Association. The 'mabalane', or mission-educated Zulu-speaking clerks, were particularly influential in the early clubs. ${ }^{81}$

\section{The state of play after 1910}

In 1906 a commentator described the 'carrying game' as having "fallen on evil days" ${ }^{\$ 2}$ in Natal. A year later the Corinthians toured for a third time and Alegi notes that "soccer was quite popular among whites on the eve of the formation of the Union 
of South Africa in 1910". ${ }^{83}$ This situation changed rapidly in the years after Union. Several factors would seem to account for the subsequent development of soccer as a subordinate code. These include the departure of the colonial regiments; the exclusion of soccer from the post-1910 education system; the contrasting roles played by international fixtures in integrating the local football fields into transnational fields, and the particular role that early international rugby success played in forging a national white identity; and the emerging status of soccer in African communities, where the association code provided a means of contesting urban space and forging pan-African identities and solidarity.

The British military played a particularly significant role in establishing and maintaining soccer clubs - in urban areas in general and the Transvaal in particular. One writer described the years between 1902 and 1912 as 'the military decade', when soccer progressed very rapidly. He goes on the mention the decline of soccer - by implication among whites - "from the date of the departure of the military from the Transvaal". ${ }^{84}$

Rugby's dominance over soccer is acknowledged in the following quotation, taken from a sports summary published in 1913.

The game has, of course, been taken up with enthusiasm by the schools all over the country, with the exception of the Western Province, and in the younger generation there may be one or two destined to gain distinction against future overseas teams. But even if this happens the day is far distant when the South African Soccer player will be able to hold his own with the world's best as our Rugby players have done. ${ }^{85}$

The 'exception of the Western Province' is quite significant, given that the education system of this province - the core of the old Cape Colony - served as the blueprint for the national education system that emerged after Union. In 1916 Parliament passed three Acts: the first two established the Universities of Stellenbosch and Cape Town as the first autonomous teaching universities; the third made provision for the 
relocation of the University of the Cape of Good Hope to Pretoria, where it was reestablished as the University of South Africa. Inter-collegiate rugby had long been established between the two Cape colleges, ${ }^{86}$ and this tradition soon spread to other tertiary institutions established under the umbrella of the national examining university. Rugby also took root in the schools, such that by 1928 the South African Football Association ruefully acknowledged the exclusion of soccer at all levels of the education system. ${ }^{87}$

The quotation cited above also reflects the growing fear among white footballers that their sport was not performing on a par with rugby. International encounters with the 'home country' constituted the initial yardstick against which the two codes were measured. An 'FA team' visited South Africa in 1910 and was not seriously tested by the local teams. By the time of the first UK football tour in 1924, the rugby springboks had already established a dominant record against their English counterparts. While these wins served to popularize rugby among whites, success at rugby also helped to forge a generic sense of white nationalism, which would underpin the subsequent development of Afrikaner nationalism. ${ }^{88}$ At an international level, rugby was more conducive to white identity formation and elite closure than soccer. Both rugby and soccer players during this period tended to overstate the individual 'genius' of the rugby players and underestimate the social difficulties attending soccer's integration into a quantitatively and qualitatively different transnational field. ${ }^{89}$ Success in a relatively small transnational field, defined by amateurism and the shared white class habitus of the southern dominions, therefore bolstered rugby's status as the code of choice in the unified-but racially exclusive — post-1910 field of 'national sports'. 
Between 1910 and 1948 rugby played a significant role in mobilizing a white Afrikaner nationalist identity. This process culminated in the election of the National Party and, beginning in 1956, attempts to formulate a formal apartheid policy for sport. Long before this date however, many of the official sporting codes had clauses in their constitutions restricting membership "to persons of White descent". 90 In the years after Union, white footballers were certainly intent on retaining a similar exclusivity. They were nevertheless faced with a much larger and more culturally complex transnational field; one in which the opportunities for national elite closure were far more limited. And it was these conditions that also made soccer available for appropriation as a shared subaltern code among newly urbanized African communities. The rapid rise of rugby (along with cricket) as a dominant form of cultural capital in the emerging white-dominated urban economy, therefore left the association code available for appropriation-particularly as a form of institutionalized cultural capital ${ }^{91}$ — by urban Africans and other minority groups, for whom it served as a pastime, a means of urban integration and a tool of struggle.

\section{Conclusion}

This article began with a discussion of the ambiguity associated with the term 'football' and proceeded to explore how thinking about the modern game of soccer as a 'sporting code' can facilitate an understanding of its historical development. I noted the historical shift in the use of the term 'code': from law to language, sports and other cultural domains. The second section noted the hydraulic association with the term 'diffusion', which I argued tended to obscure social dynamics and the conflict that always accompanies the distribution of a powerful cultural code. For this reason, cultural codes may better be said to 'accumulate' within stratified social systems, and 
as such can be reconceptualised as varieties of cultural capital. Drawing on the work of Bourdieu, I elaborated three general manifestations of cultural capital: codes that tend to accumulate in embodied, objectified and institutionalized states. Through a brief recourse to the literature on the history of soccer in the United Kingdom, the paper outlined the emergence of rugby and soccer as relatively discrete forms of cultural capital within an Empire-wide field. By the end of the century, soccer was established as the dominant football code in the United Kingdom and was rapidly spreading to other parts of the word. Rugby retained its amateur and middle class status, which facilitated elite closure and the construction of 'white' national identities in the southern dominions.

In South Africa, rugby and soccer emerged as distinct football codes during the period between 1859 and the turn of the twentieth century. I noted how rugby and soccer formed subfields centred on the Cape Colony and the Natal Colony respectively, both of which extended inland towards the industrial heartlands of the Witwatersrand in the years after the discovery of gold in 1886 . The significance of English education systems in fostering both codes was also explored. The colonial military and the media played a significant role in promoting the association game, but this was rapidly undermined by the status attributed to rugby in the post-1910 national education system. The integration of these two local sporting fields into contrasting transnational fields changed the relative status of the two football codes in the politically unified and increasingly stratified post-1910 society. The emergence of rugby as a dominant form of sporting capital among whites coincided with the gradual appropriation of association football by urbanizing Africans and other marginalized communities. 


\section{References}

Alegi, P. Laduma! Soccer, Politics and Society in South Africa. Pietermaritzburg: University of KwaZulu-Natal Press, 2004.

Babrow, L. and R.K. Stent. The Varsity Spirit - The Story of Rugby Football at the University of Cape Town. Cape Town: Johnston \& Neville, 1963.

Bailey, P. Leisure and class in Victorian England - Rational recreation and the contest for control, 1830 - 1885. London: Routledge \& Kegan Paul, 1978.

Booley, A. Forgotten Heroes: History of Black Rugby, 1882-1992. Cape Town: Manie Booley Publications, 1998.

Boucher, M. Spes in Arduis - a history of the University of South Africa. Pretoria: University of South Africa, 1973.

Bourdieu, P. Outline of a theory of practice. Cambridge: Cambridge University Press, 1977.

'The Forms of Capital'. In Handbook of Theory and Research for the Sociology of Education, ed. J.G. Richardson, 241-258. New York: Greenwood Press, 1986.

Language and symbolic power. Cambridge: Polity Press, 1991.

'Structures, Habitus, Practices'. Elliott, Anthony, Blackwell Reader in Contemporary Social Theory. Malden: Blackwell, 1999.

Bragg, M. 12 books that changed the world. London: Hodder \& Stoughton, 2006.

Cobley, A. G. The Rules of the Game: Struggles in Black Recreation and Social Welfare Policy in South Africa. Westport, CT: Greenwood Press, 1997.

Cohen, R. Global Diasporas - An introduction. London: UCL Press, 1997.

Collins, T. Rugby's Great Split - Class, Culture and the Origins of Rugby League Football. New York: Routledge, 2006.

Couzens, Tim. 'An introduction to the history of football in South Africa'. In Town and Countryside in the Transvaal: Capitalist Penetration and Popular Response, ed. B. Bozzoli', 198-215. Johannesburg: Ravan Press, 1983.

Cox, R., D. Russell and W. Vamplew. Encyclopedia of British Football. London: Routledge, 2002.

Difford, I. D. The History of South African Rugby Football. Cape Town: The Speciality Press of S.A., 1933.

Draper, M. Sport and Race in South Africa. Johannesburg: South African Institute of Race Relations, 1963.

FIFA Museum Collection - 1000 years of Football. Berlin: edition q, 1996.

Gibson, A. and W. Pickford. Football \& the men who made it (South African Edition). Cape Town: D.E. McConnell \& Co., 1906.

Grundlingh, Albert, A. Odendaal, and B. Spies. Beyond the Tryline: Rugby and South African Society. Johannesburg: Ravan Press, 1995.

Goldblatt, D. The ball is round: a global history of football. London: Viking, 2006.

Hattersley, A. F. Pietermaritzburg Panorama: A Survey of One Hundred Years of an African City. Pietermaritzburg: Shuter and Shooter, 1938.

Herbert, A. The Natal Rugby Story. Pietermaritzburg: Shuter \& Shooter, 1980.

'La Soule, ancêtre du rugby et du football'. Revue la France Pittoresque 25 (2008).

Leith, D. and L. Jackson. 'The Origins of English'. In Changing English, ed. D. Graddol, D. Leith, J. Swann, M. Rhys and J. Gillen, 39-73. Abingdon: Routledge, 2007.

Mangan, J.A. and C. Hickey. Early inspiration: athleticism and colleges'. Soccer \& Society 9, no. 5 (2008): 607-631. 
Parker, G.A. South African Sports. London: Sampson Low, Marston, and Company, 1897.

Raath, P. Soccer through the years: 1862-2002. Cape Town: R. Raath, 2002.

Sports and Sportsmen South Africa. Cape Town: Aitkinson and Partners, 1929.

Swaffer, H. P. South African Sport. Johannesburg: Transvaal Leader, 1914.

Taylor, M. The Association Game - A History of British Football. London: Pearson, 2008.

Williams, R. Keywords - A vocabulary of culture and society. London: Fontana Press, 1976.

\section{Notes}

${ }^{1}$ I would like to thank Peter Alegi and Natasha Erlank for comments made on an earlier draft of this article. The article was written in close collaboration with Chris Bolsmann, to whom I am particularly indebted for both comments and material.

${ }^{2}$ Choices with respect to racial nomenclature are always difficult, but cannot be avoided. In this paper my unmarked references to race (e.g. black and not 'black') follow current South Africa legal conventions, in terms of which 'black' is a coverall term that includes 'Africans', 'Indians' and 'coloureds.'

${ }^{3}$ Calques include Fußball (German), fútbol (Spanish) and voetbal (Dutch and Afrikaans).

${ }^{4}$ FIFA Museum Collection, 22.

${ }^{5}$ Taylor, The Association Game, 19-21.

${ }^{6}$ Leith and Jackson, The Origins of English, 65.

${ }^{7}$ FIFA Museum Collection, 27; La Soule, ancêtre du rugby et du football.

${ }^{8}$ Williams, Keywords - A vocabulary of culture and society, 307.

${ }^{9}$ Oxford English Dictionary (OED).

${ }^{10}$ Williams, Keywords - A vocabulary of culture and society, 307

${ }^{11}$ Bourdieu, Language and symbolic power, :49.

${ }^{12}$ Bourdieu, Language and symbolic power, 64.

${ }^{13}$ Bourdieu, 'The Forms of Capital', 243. Here 'social capital', defined in terms of social obligations or 'connections', is subsumed under 'cultural capital.'

${ }^{14}$ The concept of habitus derives from Leibniz. In sociology the concept is most closely associated with the work of Norbert Elias and Pierre Bourdieu. Bourdieu (Structures, habitus, practices) defines habitus as follows: "The practices of the members of the same group or, in a differentiated society, the same class, are always more and better harmonized than the agents know or wish... The habitus is precisely this immanent law, lex insita, inscribed in bodies by identical histories, which is the precondition not only for the co-ordination of practices but also for practices of co-ordination."

${ }^{15}$ Bourdieu, Outline of a theory of practice, 168.

${ }^{16}$ The 'sports field' (c.1742, referring to cricket) is but one of many contemporary abstract senses of the word, all of which derive from the Old English word 'feld' (c.1050), referring to "plain, open land" (as opposed to woodland) (OED). Bragg (12 books that changed the world, 96) notes how the land enclosures in England crowded out folk football and prepared the field, so to speak, for the modern codes.

${ }^{17}$ Bailey, Leisure and class in Victorian England, 37.

${ }^{18}$ Collins, Rugby's Great Split, xviii. Collins notes that towards the end of the nineteenth century this was particularly true of Rugby Union.

${ }^{19}$ Mangan and Hickey, Early inspiration: athleticism and colleges, 607.

${ }^{20}$ Mangan and Hickey, Early inspiration: athleticism and colleges. 1888 is well-known as the year in which the first professional and predominantly working class National Football League was founded. It is also the year in which the Cross Commission Report recommended a closer relationship between the Oxbridge institutions and the teacher training colleges, thus promoting athleticism and football throughout the school system.

${ }^{21}$ Cohen, Global Diasporas - An introduction, 202.

${ }^{22}$ Goldblatt, The ball is round, 52.

${ }^{23}$ Taylor, The Association Game, 37.

${ }^{24}$ Cox, Russell and Vamplew, Encyclopedia of British Football, 243.

${ }^{25}$ Taylor, The Association Game, 21. 
${ }^{26}$ Collins, Rugby's Great Split, 3. There is no evidence to support the myth - codified by the c. 1900 plaque at Rugby school - that in 1823 Ellis "first took the ball in his arms and ran with it."

${ }^{27}$ Cox, Russell and Vamplew, Encyclopedia of British Football, 243.

${ }^{28}$ Cox, Russell and Vamplew, Encyclopedia of British Football, 243. The Harrow and Eton codes also formed the basis of the Sheffield Rules, which were first published in 1856.

${ }^{29}$ Taylor, The Association Game, 30.

${ }^{30}$ Bragg, 12 books that changed the world, 94.

31 'Soccer' is first attested in 1895, but the earlier variations 'socca' and 'socker' are attested in 1889 and 1891 respectively. These terms emerged in contradistinction to 'rugger', which although first recorded in 1893, probably antedates 'soccer' in the spoken medium. This is very likely, given the existence of an older sense of 'rugger' as 'a plunderer, depredator, robber', which dates from 1570 (OED).

${ }^{32}$ Goldblatt, The ball is round.

${ }^{33}$ FIFA Museum Collection, 149.

34 'Origins of the Inflatable Ball', http://www.richardlindon.com/4.html.

${ }_{35}$ Bragg, 12 books that changed the world, 109.

36 'Origins of the Inflatable Ball', http://www.richardlindon.com/4.html.

${ }^{37}$ The FIFA Museum Collection - 1000 years of Football provides an excellent visual record.

${ }^{38}$ Babrow and Stent, The Varsity Spirit, 2. The name was derived from the legible letters in Ogilvie's signature. The Cape game is commonly referred to as 'the Winchester code' in South African sport histories.

${ }^{39}$ Difford, The History of South African Rugby Football, 12; Herbert, The Natal Rugby Story, 1.

${ }^{40}$ Alegi, Laduma!, 15.

${ }^{41}$ Some running with the ball was permitted in the Cape game, but Babrow and Stent (The Varsity Spirit, 8) comment that "the immediate appeal of rugby lay in the wider freedom it gave to handling."

${ }^{42}$ Cape Argus, 21 August 1862.

${ }^{43}$ Eastern Province Herald, Friday 23 May 1862.

${ }^{44}$ Hattersley, Pietermaritzburg Panorama.

${ }^{45}$ Babrow and Stent, The Varsity Spirit, 5. This source indicated the rise of a 'colonial-born versus mother country' competitive ethos in Cape football before the introduction of the game to Stellenbosch.

${ }^{46}$ Babrow and Stent, The Varsity Spirit, 4.

${ }^{47}$ Booley, Forgotten Heroes, 11.

${ }^{48}$ Booley, Forgotten Heroes, 42.

${ }^{49}$ Difford, The History of South African Rugby Football, 13-14.

${ }^{50}$ Herbert, The Natal Rugby Story.

51 'The History of Hilton College', http://www.hiltoncollege.com/history/index.htm.

${ }^{52}$ Herbert, The Natal Rugby Story, 4.

${ }^{53}$ Parker, South African Sports, 89.

${ }^{54}$ Herbert, The Natal Rugby Story, 7; Gibson and Pickford, Football \& the men who made it (South African Edition), 233.

${ }^{55}$ Boucher, Spes in Arduis - a history of the University of South Africa, 80. Boucher notes that after the Extension Act of 1875, which extended the potential jurisdiction of the University of the Cape of Good Hope, "the smaller British colony stimulated higher education by providing financial assistance for those who wished to attend universities abroad."

${ }^{56}$ Alegi, Laduma!, 16.

${ }^{57}$ Herbert, The Natal Rugby Story, 6.

${ }^{58}$ Couzens, 'An Introduction to the History of Football in South Africa', 203.

${ }^{59}$ Parker, South African Sports, 91.

${ }^{60}$ Parker, South African Sports, 91.

${ }^{61}$ Saunders, Illustrated History of South Africa - The Real Story, 230-233.

${ }^{62}$ Parker, South African Sports, 62.

${ }^{63}$ Alegi, Laduma!, 16.

${ }^{64}$ Parker, South African Sports, 2.

65 'Africaander', 'Africander' and 'Afrikander' are predecessors of the contemporary term 'Afrikaner.' Coined by way of an analogy with 'Hollander', the earliest reference (1822) refers to "those who are born in the colony [and] speak that language [sc. Dutch], and call themselves Africaanders, whether of Dutch, German, or French origin." By the end of the century the term 'Afrikander' was increasingly used to refer to "any African-born white person, whether of Dutch, English, or German origin..." (OED). 


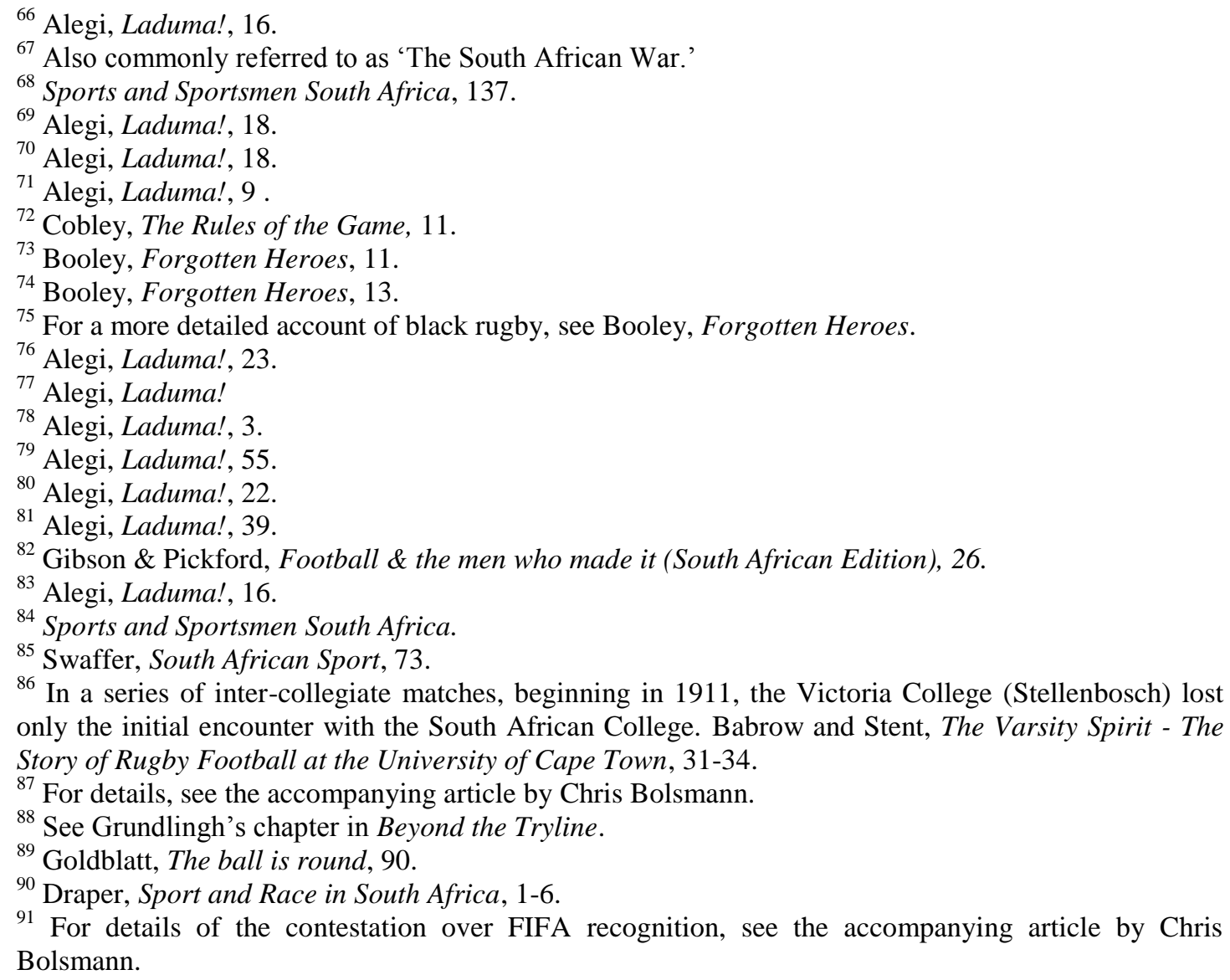

